\title{
The regulation of harmful tax competition in the EAC: current status, challenges, and ways forward
}

\author{
by Pie HABIMANA*
}

\begin{abstract}
Harmful tax competition is a topic that is globally and hotly discussed. For the past three decades, research on this topic consistently increased. Globally, states have been engaged in different projects aiming at regulating that phenomenon. Because of its international character, most of, if not all, the successful initiatives were undertaken under the auspices of regional organizations. The European Union and the Organization for Economic Cooperation and Development are good examples. This paper studies the current regulation of harmful tax competition in the East African Community. It shows how the EAC has not yet developed a sufficient regulatory approach against harmful tax competition. It also reflects on the challenges thereto related and proposes some actions that EAC needs to undertake to revamp the regulatory situation of harmful tax competition. In consideration of the harmful effects of harmful tax competition, this paper instigates the EAC partner states to stop disregarding harmful tax competition and recommends adopting a Code of Conduct against harmful tax competition in the EAC.
\end{abstract}

\section{A. Introduction}

Tax competition, harmful tax competition, and harmful tax practices usually come in the studies of international tax law. Worldwide, there is growing research literature on (harmful) tax competition. Some of such research date three decades ago ${ }^{1}$ while others were published very recently. ${ }^{2}$ More especially, under the auspices of the European Union (EU) and the Organization for Economic Cooperation and Development (OECD), several works have been undertaken on the very topic. The trigger point was the EU Code of Conduct on busi-

* Pie HABIMANA, PhD candidate in International Tax Law at Leiden University. Lecturer at the University of Rwanda, School of Law. Senior Partner in Amilex Chambers. Vice-President East Africa Law Society.

1 See for example J Bossons, 'International Tax Competition: The Foreign Government Response in Canada and other Countries' (1988) Nat'l Tax J. 41(3); B L Benson, 'Interstate Tax Competition, Incentives to Collude, and Federal Influences' (1990) Cato Journal 10(1); H-W Sinn, 'Tax Harmonization and Tax Competition in Europe' (1990) National Bureau of Economic Research WP 3248.

2 See for example L V Faulhaber, 'The Trouble with Tax Competition: From Practice to Theory' (2018) Tax L.Rev. 71(311); I O Ozai, 'Tax Competition and the Ethics of Burden Sharing' (2018) Fordham Int'lL.J. 42(1); M C Durst, 'Poverty, Tax Competition, and Base Erosion' (2018) Tax Notes International 89(12); F G Morina, 'The Legal Aspect of the Tax Competition in EU: Case of Kosovo' (2019) Sriwijaya L.Rev. 3(1). 
ness taxation adopted by the ECOFIN Council meeting of 1 December $1997^{3}$ and the OECD Report of 1998 named 'Harmful Tax Competition: An Emerging Global Issue'. 4

Even though, as far as the East African Community (EAC) is concerned, there is as yet little which addresses the same topic. ${ }^{5}$ Compared to the EU that significantly advanced in regulating harmful tax competition, the EAC regulatory framework in that matter is still embryonic. Rather, the harmful tax competition stands as a global issue that leaves no state behind the scene. The OECD voiced that as follows: 'Harmful tax competition is by its very nature a global phenomenon and therefore its solution requires global endorsement and global participation'. ${ }^{6}$ OECD added that even non-member countries 'are either seriously affected by harmful tax practices or have potentially harmful regimes'. 7 Thus, the EAC partner states, like other states, are not out of the game of harmful tax competition. In other words, the EAC partner states are either affected by harmful tax practices or have potential harmful tax regimes. This understanding, coupled with the harmful consequences of harmful tax competition on the citizens' welfare, justify the necessity of regulating harmful tax competition in the EAC. Unfortunately, the EAC is still struggling to have concrete regulatory instruments that can effectively counteract harmful tax competition within the Community.

That makes the subject of this paper, which aims at analyzing the current status of harmful tax competition in the EAC, the challenges thereto related, and the best ways forward that can be proposed. Thus, this paper's objectives are summarized into three namely the exploration of the current regulation, the determination of the challenges that are hindering a proper regulation, and the suggestion of what can be done to overcome such challenges towards an effective regulation of harmful tax competition in the EAC.

The production of this paper was mainly based on the doctrinal legal approach through the analysis of currently documented information. This focused on the publicly available EAC legal instruments, both in force and not yet in force, plus scholarly analyses on related topics. The desk research was used to collect the information herein presented.

This paper is structured into seven sections, introduction and conclusion included. After the introduction, the second section briefly introduces the EAC as regional integration and its legal order. The third section attempts to simplify the understanding of harmful tax competition, while the fourth section summarizes the current EAC legal instruments in relation to harmful tax competition. The fifth section reflects on the challenges that the EAC is fa-

3 EU Code of Conduct 1997: Conclusions of the ECOFIN Council meeting of 1/12/1997 concerning taxation policy DOC 98/C2/01, OJEC (6.1.98).

4 OECD (1998), Harmful Tax Competition: An Emerging Global Issue, Paris, OECD Publishing.

5 For the specific situation of Rwandan law, see P Habimana, 'Tax Competition: Global but Virgin under Rwandan Law' (2020) Recht in Afrika 23(1).

6 OECD (2000), Towards Global Tax Co-operation: Progress in Identifying and Eliminating Harmful Tax Practices, Report to the 2000 Ministerial Council Meeting and Recommendations by the Committee on Fiscal Affairs, Paris, OECD Publications, p. 22.

7 Ibid. 
cing while regulating harmful tax competition. Following that, the sixth section proposes and recommends actions that EAC can undertake to effectively regulate harmful tax competition. Thereafter comes the conclusion.

\section{B. EAC and EAC law in brief}

The focus of this paper is the harmful tax competition in the EAC. By nature, tax competition can be studied from different perspectives: legal, economic, political, etc. I do the current study from a legal perspective. In this respect, it is important to first describe the EAC and its law before discussing the EAC regulatory aspects of harmful tax competition.

\section{EAC in brief}

The EAC is one of the eight regional economic communities recognized by the African Union (AU). ${ }^{8}$ The EAC is considered as Africa's oldest regional integration. ${ }^{9}$ This consideration is based on some initiatives that have existed a century ago, which are considered being the foundations of the current EAC. Such initiatives are, for example, the project on the construction of the railway between Kenya and Uganda from 1897 to 1901; the establishment of a Customs Collection Centre in 1900; the establishment of an East African Currency Board and a Postal Union in 1905; the establishment of a Court of Appeal for Eastern Africa in 1909; the establishment of a Customs Union in 1919; the establishment of an East African Income Tax Board and a Joint Economic Council in 1940. ${ }^{10}$

Besides those initiatives, a formal East African Community was created in 1967. By that time it was composed of three countries, namely Kenya, Tanzania, and Uganda. Unfortunately, the EAC collapsed ten years later, that was in 1977. Fortunately, the three founding members revived the EAC in 1999, and thereafter admitted new members. Currently, the EAC is composed of six partner states, namely Kenya, Tanzania, and Uganda that are the initial partners of the EAC, Burundi and Rwanda that adhered to the EAC in 2007 and

8 C Nalule, Advancing Regional Integration: Migration Rights of Citizens in the East African Community, (Ph.D Thesis, Witwatersrand University 2017), p. 74.

9 A T Marinho and C N Mutava, 'Tax Integration within the East African Community: A Partial Model for Regional Integration in Africa', p. $1<$ https://pdfs.semanticscholar.org/3cd7/ce 5 b507d7a 04acd640dfb37401d6aebc33f6.pdf $>$ accessed 27/03/2020.

10 Id., p. 2; J A Mgaya, Regional Integration: The Case of the East African Community, (MA Thesis, Australian National University 1986), pp. 2-3; W Masinde and C O Omolo, 'The Road to East African Integration', in E Ugirashebuja, J E Ruhangisa, T Ottervanger and A Cuyvers (eds), East African Community Law: Institutional, Substantive and Comparative EU Aspects (Brill Nijhoff 2017), p. 15; A Titus, 'How Can the East African Community Guard against Base Erosion and Profit Shifting while Working towards Deeper Integration? Lessons from the European Union' (2017) WTJ, p. 574; J Otieno-Odek, 'Law of Regional Integration: A Case Study of the East African Community', in J Döveling, H I Majamba, R F Oppong and U Wanitzek (ed), Harmonization of Laws in the East African Community: The State of Affairs with Comparative Insights from the European Union and other Regional Economic Communities (LawAfrica Publishing 2018), p. 19. 
South Sudan which adhered in 2016. The EAC territory covers 2,462 thousand $\mathrm{km}^{2}$ with 177.2 population by mid-2018. ${ }^{11}$

The EAC is governed through organs and institutions. Currently, the EAC counts 7 organs, namely the Summit, the Council, the Coordination Committee, the Sectoral Committees, the East African Court of Justice (EACJ), the East African Legislative Assembly (EALA), and the Secretariat. ${ }^{12}$ The Summit is the top organ of the Community. It is composed of the Heads of States or Governments. It has a mandate of giving the general directions and impetus towards the development and achievement of the EAC objectives. ${ }^{13}$ Below the Summit is the Council of the Ministers. This is the policy organ which is composed of the ministers responsible for the EAC matters, other ministers that the partner states may determine, and the partner states' attorneys general. ${ }^{14}$ Chapter 8 and 9 of the Treaty respectively detail the EACJ and the EALA matters. Chapter ten details the mandate of the Secretariat, which stands as the Community's executive organ. ${ }^{15}$ Besides those organs, EAC also counts nine semi-autonomous institutions. ${ }^{16}$

Regarding the processes of regional integration, the Treaty provides for four stages. ${ }^{17}$ Such are the customs union, which is already established and fully functioning since 01 January 2005; the common market whose protocol was signed on 01 July 2010 and currently partially implemented; the monetary union whose Protocol was signed on 30 November 2013; and the political federation which has not yet started.

The structure and governance of the EAC coupled with the stages of regional integration that are so far achieved show to what extent EAC currently stands as a viably functioning regional organization. That couples with the EAC legal instruments, whose brief details are developed below.

\section{EAC law in brief}

In a comparative lens, the EAC is comparable to the EU. Both have a long-standing history as the oldest regional integrations. Both are also the most developed in their respective

11 EAC Secretariat, 'East African Community Facts and Figures', Nov. 2019, p. 11 and $14<$ file://C: /Users/HP/Downloads/EAC\%20Facts\%20Figures\%202019.pdf $>$ accessed 02/11/2020.

12 Treaty for the Establishment of the East African Community (As amended on 14/12/2006 and 20/08/2007), art. 9(1).

$13 I d$., art. 10(1) and 11(1).

14 Id., art. 14.

15 Id., art. 66.

16 Such are the East African Development Bank, the Inter-University Council for East Africa, the East African Science and Technology Commission, the East African Health Research Commission, the East African Competition Authority, the Civil Aviation Safety and Security Oversight Agency, the East African Kiswahili Commission, the Lake Victoria Fisheries Organization, and the Lake Victoria Basin Commission. See EAC, EAC Institutions < https://eac.int/eac-institutions> accessed 18/03/2020.

17 EAC Treaty (n 12) art. 5(2). 
continents, i.e. EU in Europe and EAC in Africa. In addition, the treaties that respectively govern the EU and the EAC also have some resemblance. ${ }^{18}$ It is on those bases that some authors affirm that the EAC looks like an African model of the EU in Europe. ${ }^{19}$

Unfortunately, in contrast to the EU, which has a well-developed legal order, the EAC has not so far developed a legal order pure to the EAC. Consequently, most of the legal issues in the EAC are practically handled domestically, while only very few are handled at the community level. Even though, the EAC is theoretically equipped with a good number of legal instruments, which are strong enough to create a good legal order of the EAC. An example of such legal instruments is the EAC Treaty.

Under EAC law, the term Treaty comprises the Treaty itself and its annexes and protocols that can supplement, amend, or qualify it. ${ }^{20}$ The Treaty is the highest EAC legal instrument and serves as the principal source of law. Other sources of law include the EACJ procedural rules ${ }^{21}$ and the EACJ precedents as witnessed in several judgments. ${ }^{22}$

The above legal and institutional framework of the EAC was developed to pave the way towards this paper's major focus. Even so, before diving into that, it is important to introduce the tax competition phenomenon in its general aspects.

18 Marinho and Mutava (n 9) p. 2.

19 S O Oyetunde, The Role of Tax Incentives in a Trio of Sub-Saharan African Economies: A Comparative Study of Nigerian, South African and Kenyan Tax Law (Ph.D Thesis, Queen Mary University of London 2008), p. 280; $H$ G Petersen (ed), 'Tax Systems and Tax Harmonization in the East African Community' (2010) Report for the GTZ and the General Secretariat of the EAC, p. 13; N Huls, 'Constitutionalism à la Rwandaise', in M Adams, A Meuwese and E H Ballin (eds), Constitutionalism and the Rule of Law: Bridging the Idealism and Realism (CUP 2017), p. 218.

20 EAC Treaty (n 12) art. 1 and art. 151(4).

21 Id., art. 42(1).

22 EACJ, Appellate Division, Appeal No. 2 of 2011, Alcon International Limited and The Standard Chartered Bank of Uganda, The Attorney General of Uganda and Registrar of the High Court of Uganda, 16/03/2012, para. 18 and 19; EACJ, Appellate Division, Appeal No. 3 of 2011, The Attorney General of the United Republic of Tanzania and African Network for Animal Welfare (ANAW), 15/03/2012, para. 23, 24, and 31; EACJ, First Instance Division, Ref. No. 1 of 2014, East Africa Law Society v. The Attorney General of the Republic of Burundi and The Secretary General of the East African Community, 15/05/2015, para. 33 and 53; EACJ, First Instance Division, Ref. No. 1 of 2011, The East African Law Society v. The Secretary General of the East African Community, 14/02/2013, p. 10, 11, 12, 14, 15, and 20; EACJ, First Instance Division, Ref. No. 6 of 2011, Democratic Party and Mukasa Mbidde v. The Secretary General of the East African Community and the Attorney General of the Republic of Uganda, 10/05/2012, para. 18, 33, and 44; EACJ, First Instance Division, Ref. No. 10 of 2011, Legal Brains Trust (LBT) Limited v. The Attorney General of the Republic of Uganda, 30/03/2012, para. 68; EACJ, First Instance Division, Ref. No. 11 of 2011, Mbugua Mureithi wa Nyambura v. The Attorney General of the Republic of Uganda \& The Attorney General of the Republic of Kenya and Avocats sans Frontières (Amicus Curiae), 24/02/2014, para. 36, 56, 61, 62, and 63. 


\section{A brief understanding of tax competition}

Tax competition is a long-standing phenomenon. Broadly considered, some authors affirm that some elements of tax competition existed a long time ago, such in the antiquities, and in the middle age periods. ${ }^{23}$ Currently, tax competition is practiced globally and can be studied from different perspectives such as legal, economic, political, etc.

From a legal perspective, the center and hardcore element of tax competition is the principle of state sovereignty. According to this principle, every state is independent and free to self-determination. Taken as a whole, state sovereignty is structured into different sovereignties, including state tax sovereignty. This includes the rights and powers to regulate the fiscal matters by freely setting up a tax system that a state considers to be the best in consideration of its particular features, and its political, economic, and legal programs. That regulatory freedom, coupled with the states' competitiveness desire, pushes the states to set up tax systems which are favorable to businesses. In this respect, an implied aim of that competition is to set up a tax system that is the most investment-friendly, first in the region, and then worldwide. At this level, tax competition stands healthy for national interest, i.e. for the state itself, for investors, and for the general population.

Be that as it may, each state's desire to engage in tax competition leads to a process of retaliation through which each state aims at using tax competition tools, which are much better than the tools used by other states. Some commonly used fiscal tools include tax exemptions and reductions, either by reducing the tax rates, or by narrowing the tax bases, or by relaxing the tax procedures. At this level, still, the states' endeavors fall within the states' tax sovereignty, and tax competition still, stands not as a bad thing.

The problem arises when the tax competition becomes harmful. Technically, tax competition, which by nature is not bad, becomes harmful when the spillover effects go beyond the competing state to affect other states. This happens when the competing state set up strategies to attract the tax base of other states. At this level, the aim is to gain a large share part in the international tax base. If done gently no problem, but if done not gently it becomes problematic because it puts other states in a suffering situation. This spillover makes states losing the fiscal revenues that they would receive would other states not harmfully competed.

Fueled by globalization, states noticed, from time to time, the increase of the spillover effects of harmful tax competition. Thus, the states could not stay inactive in front of situations that are diminishing their abilities to provide the essential needs to their citizens. Counteracting actions were really needed. This pushed the states to undertake a variety of initiatives aiming at defending their tax bases from being eroded. In this exercise, the regional organizations played a significant role. Without undermining other organizations' roles, the works of the EU and the OECD are the most significant.

23 D Kamanzi, 'De quel type de zone franche le Rwanda a-t-il besoin?' (1999) L.Rev. 3, p. 55; G A McCarthy, 'Promoting a More Inclusive Dialogue', in R Biswas (ed), International Tax Competition: Globalization and Fiscal Sovereignty (Commonwealth Secretariat 2002), p. 36. 
Starting with the EU, this organization issued the Code of Conduct on business taxation on 01 December 1997. This Code, besides setting 'lower effective level of taxation than those levels which generally apply' as the gateway criterion or initial criterion, ${ }^{24}$ elaborated on five criteria to determine harmful tax measures as follows:

(1) whether advantages are accorded only to non-residents or in respect of transactions carried out with non-residents; or (2) whether advantages are ring-fenced from the domestic market, so they do not affect the national tax base; or (3) whether advantages are granted even without any real economic activity or substantial economic presence; or (4) whether the rules for profit determination in respect of activities within a multinational group of companies depart from internationally accepted principles, notably the rules agreed upon within the OECD; or (5) whether the tax measures lack transparency, including where legal provisions are relaxed at administrative level in a non-transparent way. ${ }^{25}$

The Code's criteria are summarized as offering a lower level of taxation, ring-fencing, lack of substantial activity, lack of arm's length dealing, and lack of transparency. ${ }^{26}$ In that regard, a tax measure is harmful if it results in a significantly lower level of taxation, is ringfenced, is not respecting arm's length principles, and it lacks substantial activity and transparency.

Though not legally binding, the EU Code of Conduct received a high-level political support that strongly contributed to its success. In the same vein, a Code of Conduct Group (COCG) has been created in March 1998 to monitor the implementation of the Code of Conduct. Since that time, the COCG conducted several assessments using the five criteria elaborated on by the Code of Conduct. By December 2019, the number of assessments

24 EU Code of Conduct (n 3) C 2/3 para. B; R Teather, 'The Benefits of Tax Competition' (2006) IEA Hobart Paper No. 153, p. $135<$ https://papers.ssrn.com/sol3/papers.cfm?abstract_id=878438> accessed 03/08/2019; S Bond et al., Corporate Tax Harmonization in Europe: A Guide to the Debate (2000) The Institute for Fiscal Studies, London, p. $62<$ www.ifs.org.uk/comms/r63.pdf $>$ accessed 24/08/2019, p. 55; H Nijkamp, 'EU Stands up to Harmful Regimes' (2001) Int'lT. Rev. 12(3), p. 35; Council of the European Union, The EU list of non-cooperative jurisdictions for tax purposes, FISC 345 ECOFIN 1088, 15429/17, Brussels, 5/12/2017, OJEU, Vol. 60, 19.12.2017, C 483/13, p. 32; W B Barker, 'Optimal International Taxation and Tax Competition: Overcoming the Contractions' (2002) Nw.J.Int'lL. \& Bus. 22(161), p. 170; I Calich, The Impact of Globalization on the Position of Developing Countries in the International Tax System (Ph.D Thesis, The London School of Economics and Political Science 2011), p. 60 and 63; W Bratton and J A McCahery, 'Tax Coordination and Tax Competition in the European Union: Evaluating the Code of Conduct on Business Taxation' (2001) CML Rev. 38, p. 685.

25 EU Code of Conduct (n 3), C 2/3; M Seeruthun-Kowalczyk, Hard Law and Soft Law Interactions in EU Corporate Tax Regulation: Exploration and Lessons for the Future (Ph.D Thesis, Edinburgh University 2011), p. 172.

26 B J M Terra and P J Wattel, European Tax Law (5 ${ }^{\text {th }}$ edn, Kluwer 2008), p. 112. 
conducted by COCG amounted to over $700 .{ }^{27}$ The COCG also developed further explanations of the five criteria through its Agreed Guidance. ${ }^{28}$

Besides, the OECD direct initiatives against harmful tax competition started in 1996 at the Lyon summit. During this summit, it was stated:

Finally, globalization is creating new challenges in the field of tax policy. Tax schemes aimed at attracting financial and other geographically mobile activities can create harmful tax competition between states, carrying risks of distorting trade and investment and could lead to the erosion of national tax bases. We strongly urge the OECD to vigorously pursue its work in this field, aimed at establishing a multilateral approach under which countries could operate individually and collectively to limit the extent of these practices. ${ }^{29}$

Following that, in 1998, the OECD issued the first report named 'Harmful Tax Competition: An Emerging Global Issue'. Though not supported by some, the OECD members and non-members included, the report had more successes than failures. The 1998 Report broke down the phenomenon of harmful tax competition into two components, namely tax havens and harmful preferential tax regimes. ${ }^{30}$ While tax havens refer to an entire jurisdiction, harmful preferential tax regimes refer to tax regimes within a jurisdiction. Furthermore, a simple technical difference between the two is indicated as follows:

Tax havens have no interest in preventing the race to the bottom, are actively contributing in the tax base erosion of other countries and are unlikely to cooperate in cur-

27 Council of the European Union, Overview of the preferential tax regimes examined by Code of Conduct Group since its creation in March 1998, 9639/4/18 REV 4 FISC 243 ECOFIN 557, Brussels, 5/12/2019<https://data.consilium.europa.eu/doc/document/ST-9639-2018-REV-4/en/pdf> accessed 24/04/2020.

28 Council of the European Union, Agreed Guidance by the Code of Conduct Group (business taxation): 1998-2018, FISC 44 ECOFIN 75, 5814/4/18 REV 4, Brussels, 20/12/2018.

29 S Jogarajan and M Stewart, 'Harmful Tax Competition: Defeat or Victory?' (2007) Austl.Tax.F. 22, p. 5; K van Raad, Materials on International \& EU Tax Law (13 ${ }^{\text {th }}$ edn, International Tax Center 2013), p. 1309.

30 OECD 1998 (n 4) p. 7; OECD (2019), Harmful Tax Practices - 2018 Progress Report on Preferential Regimes: Inclusive Framework on BEPS Action 5, Paris, OECD Publishing, p. 41; Littlewood, 'Tax Competition: Harmful to Whom?' (2004) MichJIntlL 26(1), p. 413 and 419; Jogarajan and Stewart, Id., p. 8; J McLaren, Will Tax Havens Survive in the New International Legal Environment? (Ph.D Thesis, RMIT University 2010), p. 91; D Fabris, 'To Open or to Close the Box: Patent Box Regimes in the EU between R\&D Incentives and Harmful Tax Practices' (2019) Amsterdam Law Forum 11(1), p. 47; D S Smit, Freedom of Investment between EU and non-EU Member States and its Impact on Corporate Income Tax Systems within the European Union (Ph.D Thesis, Tilburg University 2011), p. 195; M Wróblewska, 'Harmful Tax Competition in a Globalized World: Does the World Trade Organization Deal with this Issue?' (2016) Studia Iuridica 1, p. 17; J B Kiprotich, Income Tax in the East African Community: A Case for Harmonization and Consolidation of Policy and Law with a Focus on Corporate Income Taxation (Ph.D Thesis, University of Nairobi 2016), p. 52; H Gribnau, 'The Integrity of the Tax System after BEPS: A Shared Responsibility' (2017) ELR 1, p. 20. 
bing harmful tax competition whereas countries with harmful preferential regimes may have a significant amount of revenues which are at risk, therefore have an interest in eliminating harmful tax competition on a concerted action i.e. on condition that other countries do the same. ${ }^{31}$

Thus, in consideration of the distinctive elements between tax havens and harmful preferential tax regimes, the OECD elaborated on the factors that characterize each component of harmful tax competition. Regarding the tax havens, the OECD, without actually defining what it is, established four characterizing factors namely:

(a) having no or only nominal taxes either in general or in special circumstances for non-residents, (b) having laws and/or administrative rules and/or practices which prevent the effective exchange of relevant information with other governments on taxpayers benefiting from the low or no tax jurisdictions, (c) lack of transparency and (d) absence of any requirement for substantial activity. ${ }^{32}$

Regarding the harmful preferential tax regimes, like for the tax havens, the OECD, also without actually defining what harmful preferential tax regime is, elaborated on a set of characterizing factors. The OECD subdivided those factors into two categories respectively referred to as 'key factors' and 'other factors'. The first category or key factors are four:

(a) low or zero effective tax rate on specified kinds of income such as movable sources of income, (b) ring-fencing from the domestic economy, (c) lack of transparency and (d) no effective exchange of information with other governments. ${ }^{33}$

The second category or other factors' role is to support the key factors. ${ }^{34}$ They are:

(a) an artificial definition of the tax base, (b) failure to adhere to international transfer pricing principles, (c) exemption of foreign source income from residence-country taxation, (d) negotiable tax rates or tax bases, (e) existence of secrecy provisions, ( $f$ ) access to a wide network of tax treaties, $(g)$ promotion of the regime as a tax minimi-

31 OECD 1998 (n 4) para. 43; van Raad (n 29) pp. 1314-15; F Boulogne, 'Reviewing the OECD's and the EU's Assessment of Singapore's Development and Expansion Incentive' (2019) Singapore Management University School of Accountancy Research Paper 7(1), p. $12<\mathrm{http}$ ://dx.doi.org/10.2 139/ssrn.3349404> accessed 14/08/2019; P Genschel and T Rixen, 'Settling and Unsettling the Transnational Legal Order of International Taxation', in T C Halliday and G Shaffer (eds), Transnational Legal Orders (CUP 2015), p. 174; B J Arnold and M J McIntyre, International Tax Pri$m e r\left(2^{\text {nd }}\right.$ edn, Wolters Kluwer 2002), p. 139 and 141; N Nikolakakis, The International Legal Ramifications of the OECD's Harmful Tax Competition Crusade (LL.M Thesis, McGill University 2006), p. 59.

32 OECD 1998 (n 4) p. 22.

33 Id., pp. 26-30; Joint Committee on Taxation, Background, Summary and Implications of the OECD/G20 Base Erosion and Profit Shifting Project, JCX-139-15, Nov. 2015, p. 18.

34 Van Raad (n 29) p. 1320. 
zation vehicle, and (h) encouragement by the regime of purely tax-driven operations or arrangements. ${ }^{35}$

Comparable to the COCG, the OECD, following the $15^{\text {th }}$ recommendation of the 1998 Report, established the Forum on Harmful Tax Practices in 1998 to monitor and review further harmful tax competition. ${ }^{36}$ The Forum successfully coordinated and furthered the knowledge to curb harmful tax practices ${ }^{37}$ In this respect, part of fulfilling its mandate, the Forum conducted a good number of evaluations and published several reports accordingly. In 2009, the Forum was reformed and changed its name to the Global Forum on Transparency and Exchange of Information for Tax Purposes. ${ }^{38}$ Subsequently, its mission was revised and stated as aiming at ensuring the implementation of the international standards of international cooperation in tax matters, namely the standards of transparency and exchange of information. ${ }^{39}$

While commending the EU and the OECD efforts in curbing harmful tax practices, it is important to mention that the EU and OECD members are developed countries. Consequently, the regulation by both organizations would presumably highly reflect the interests of developed countries. Regarding developing countries, and in consideration of this paper's principal focus, the EAC situation is developed below.

\section{EAC legal instruments in relation to tax competition}

The EAC legal arsenal is spearheaded by the Treaty. This contains some provisions that are, in one way or another, associated with tax competition. Besides, in 2011, with the support of the German Agency for International Cooperation (GIZ), the EAC made public a draft Code of Conduct against harmful tax competition in the EAC. The two stand as the top reference in the EAC law in regard to tax competition.

35 OECD 1998 (n 4) pp. 30-34; Joint committee on taxation (n 33) p. 18; van Raad, Id., p. 13201322; Littlewood (n 30) pp. 423-24; H M Liebman, W Heyvaert and V Oyen, 'Countering Harmful Tax Practices: BEPS Action 5 and EU Initiatives - Past Progress, Current Status and Prospects' (2016) Euro.Tax., pp. 102-03.

36 OECD (2017), Harmful Tax Practices - 2017 Progress Report on Preferential Regimes: Inclusive Framework on BEPS Action 5, Paris, OECD Publishing, p. 11.

37 Liebman, Heyvaert and Oyen (n 35) p. 103.

38 OECD Council Decision, Establishing the Global Forum on Transparency and Exchange of Information for Tax Purposes, C(2009)122/Final of 25/09/2009; J Englisch and A Yevgenyeva, 'The Upgraded Strategy against Harmful Tax Practices under the BEPS Action Plan' (2013) British L.Rev. 5, p. 627.

39 Boulogne (n 31 ) p. 11; L A Mello, Tax Competition and the Case of Bank Secrecy Rules: New Trends in International Tax Law (SJD Dissertation, University of Michigan 2012), p. 44. 


\section{EAC Treaty}

The Treaty, the Community's top legal instrument, contains some provisions that stand as pillars of regulating harmful tax competition in the Community. These are seen in the lens of tax harmonization, which is widely advocated by the EAC Treaty. The rationale behind is two-fold: first, the regional integration cannot be achieved without tax integration, ${ }^{40}$ second, tax harmonization plays an important role in mitigating tax competition. In fact, with tax competition, each state runs its own national tax incentives. ${ }^{41}$ In contrast, with tax harmonization, the concerned states endeavor at approaching the comparable key tax aspects, mostly the tax rates and the tax bases. Even though, without undermining the importance of tax harmonization in reducing the harmful tax competition, tax harmonization cannot completely eliminate harmful tax competition because comparability does not mean equality. But even so, it is important, and it looks like tax harmonization is part of the EAC agenda against harmful tax competition.

In respect of the above, some of the EAC Treaty provisions that directly deal with tax harmonization, and indirectly with tax competition are articles $75,76,82$, and 83. Starting with article 75 , this establishes the customs union on a progressive framework. Article 76 establishes a common market protocol and provides for a free movement of labor, goods, services, capital, and the right of establishment. Article 82 and 83 are part of Chapter fourteen which is dedicated to monetary and financial cooperation. Specifically, article 82(1) provides for the Partner States' undertaking to cooperate in monetary and fiscal matters including harmonization of fiscal policies, ${ }^{42}$ and the removal of obstacles to free movement of goods, services, and capital. ${ }^{43}$ Article 83 focuses on monetary and fiscal policy harmonization. More specifically, the second paragraph point (e) mentions the partner states undertaking to 'harmonize their tax policies with a view to removing tax distortions in order to bring about a more efficient allocation of resources within the Community'.

It is worth to mention that the EAC Treaty is in force. Because of its supremacy set out in its article 8(4) that: '[C]ommunity organs, institutions, and laws shall take precedence over similar national ones on matters pertaining to the implementation of the Treaty', any legal instrument that is contrary to any provision of the Treaty is void. Article 8(5) emphasizes that approach and states that 'Partner States undertake to make the necessary legal instruments to confer precedence of Community organs, institutions and laws over similar national ones' ${ }^{44}$ Article 16 also complements and reads that:

Subject to the provisions of the Treaty, the regulations, directives, and decisions of the Council taken or given in pursuance of the provisions of the Treaty shall be bin-

40 Marinho and Mutava (n 9) p. 2.

41 Petersen (n 19) p. 91.

42 EAC Treaty (n 12) art. 82(1)(b).

$43 I d$., art. 82(1)(c).

$44 I d$., art. 8(5). 
ding on the Partner States, on all organs and institutions of the Community other than the Summit, the Court and the Assembly within their jurisdictions, and on those to whom they may under the Treaty be addressed.

The above Treaty provisions show to what extent the Treaty is valued in the EAC. That is contrary to the draft Code of Conduct against harmful tax competition in the EAC that is not yet adopted. Even though still a draft, it was specifically designed to counteract harmful tax competition in the community, which justifies the relevance of its details below.

\section{Draft Code of Conduct against harmful tax competition in the EAC}

In 2011, the EAC, in partnership with the German Agency for International Cooperation (GIZ) made public a draft Code of Conduct against harmful tax competition in the EAC. This draft Code of Conduct is specifically dedicated to tax competition matters and contains several provisions that aim at counteracting harmful tax competition in the EAC. Eliminating harmful tax practices in the EAC is even expressly highlighted as the Code's objective. ${ }^{45}$ Without undermining the relevance of the rest, some provisions of the Code deserve a key focus in consideration of their technical aspects. An instance is article one which defines key terms used by the Code.

In terms of article 1(d), harmful tax competition is defined as:

A competition created within an economic block as a result of preferential tax regimes that offer tax advantages to particular entities at the detriment of other entities operating within the same country or other countries thereby putting the other entities in a less competitive position.

In alike manner, article $1(\mathrm{f})$ defines harmful tax practices as:

Tax measures by tax havens and/or preferential tax regimes that affect the location of financial and other services activities, erode the tax base of other countries, distort trade and investment patterns and undermine the fairness, neutrality and the broad social acceptance of systems.

Article 3 of the Code provides for the standstill and rollback clauses. Article 4 and 5 respectively deals with transparency and exchange of information. Article 16 of the draft Code of Conduct repeats the transparency and exchange of information matters. Regarding the exchange of information, article 5(2) refers the partner states to article 27 of the EAC Agreement on double taxation avoidance and the prevention of fiscal evasion in respect to taxes on income (EAC DTA). EAC DTA was signed on 30 November 2010. Like the Code of Conduct, so far it has not yet come into force. This is due to the fact that it has been so far

45 Draft Code of Conduct against Harmful Tax Competition in the East African Community, preamble. 
ratified by three states only, i.e. Kenya, Rwanda, and Uganda, while its article 30(1) requires the ratification of all partner states to come into force.

Article 7 of the Code of Conduct prohibits negotiable tax rates and tax bases, which it qualifies as harmful. The same article advises the partner states to review the tax laws which provide for such regimes. Article 8 talks of the transfer pricing rules while article 10 focuses on advance tax rulings. This article provides and defines the types of advance tax rulings and details the procedures to apply and issue a tax ruling. Article 11 and 12 respectively deals with the tax treaties with third countries, and state aids and subsidies. Article 13(1) regards as potentially harmful 'tax measures that provide for a significantly lower effective level of taxation, including zero taxation, than those levels which generally apply in the partner states'. The same article adds that it can be by virtue of the nominal tax rate, the tax base, or any other relevant factor, ${ }^{46}$ and provides a long list of what partner states can do to eliminate harmful tax practices. ${ }^{47}$

Article 15 of the Code of conduct determines the Code's geographical scope of application to be as broad as possible and advocates for promoting the principles therein in third countries. Article 17 provides for the assessment of harmful tax measures. This article is complemented by article 18 which states that to assess a tax measure, partner states can make reference. In terms of article 19, natural or legal persons can also make reference. Article 20 provides for a Committee to administer and assess harmful tax competition matters.

Theoretically, the draft Code of Conduct provides enough details. It is also subject to praises considering several provisions that can, once adopted, positively contribute to the fight against harmful tax competition in the EAC. That couples with the Treaty provisions enumerated above. However, the draft Code is not yet adopted, which hampers its implementation. Besides, the EAC is facing some other challenges to effectively regulate harmful tax competition. This is the subject of the next section.

\section{E. EAC challenges in regulating tax competition}

Like other organizations that deal with tax competition matters, EAC is facing several challenges in that regard. Not exhaustively, the key challenges are here below are grouped into three: political oriented challenges, technical challenges, and legal-related challenges.

\section{Lack of political will and intra-community misunderstanding}

Politically, the EAC partner states are more attached to domestic matters than to community matters. In other words, each partner state is much more concerned with national development rather than community development. Such states' individualism greatly fuel harmful tax competition because each state does its best to gain as big as possible share in the inter-

$46 I d$. , art. 13(1).

47 Id., art. 13(2). 
national tax base, sometimes through the use of harmful tax measures. More specifically, even if it would be much exaggeration to affirm that EAC partner states have a will to engage in harmful tax competition, it would not be an exaggeration to affirm that EAC partner states have a low political in the fight against harmful tax competition. This is substantiated by the fact that the initiatives that have been undertaken in this regard have so far remained embryonic without serious progress. An example of this is the draft Code of Conduct against harmful tax competition that remains a draft for over nine years. Not only this past long period, there is also no hope that it shall be adopted soon. Consequently, it risks remaining a draft for another long period with a high risk of being aborted.

Another challenge relates to the intra-community repetitive misunderstandings. From time to time, the EAC partner states engage in misunderstandings which in one way or another hamper the development of the community endeavors. For instance, during the past two years, that is 2019 and 2020, the Summit experienced frequent postponements. Even if the reasons for postponing are not in the public domain, it is less discussable that one reason behind is a political misunderstanding. It is also not disputable that frequent unnecessary postponements have negative consequences to the development of the community programs, including the initiatives fighting against harmful tax competition.

\section{Puzzlement over (harmful) tax competition}

Technically, EAC's understanding of tax competition and its related phenomenon is still a puzzle. For instance, there is a general trend of confusing tax competition and harmful tax competition. This is evidenced by several reports that advocate for the elimination of tax competition. This, if it happens, it would be a disaster considering the benefits associated with tax competition. Furthermore, tax competition is conventionally agreed upon to be a good thing. What poses problems is when tax competition escalates into harmful tax competition.

Regarding harmful tax competition, the progress made by the EAC to draft a Code of Conduct against harmful tax competition in the community is a wonderful step. However, it is unfortunate that the draft Code problematically defines harmful tax competition and harmful tax practices. Starting with harmful tax competition, the draft Code defines it as:

A competition created within an economic block as a result of preferential tax regimes that offer tax advantages to particular entities at the detriment of other entities operating within the same country or other countries thereby putting the other entities in a less competitive position. ${ }^{48}$

Technically, this article defines tax competition between undertakings. This is observable from the mentioned consequences of harmful tax competition, which are to put the benefiting entity in a privileged position at the detriment of other entities which are put in a less 
competitive position. Rather, as mentioned in section three, tax competition happens between states and not between undertakings. Thus, the definition provided by the draft Code of Conduct, instead of looking at it as attached to harmful tax competition, it would rather be seen as leaning to defining a phenomenon which is much closer to state aid or subsidy. The same definition of harmful tax competition also focuses on preferential tax regimes. Evidentially, this definition considers one component of harmful tax competition, namely harmful preferential tax regimes, and excludes tax havens, which rather make up an important component of harmful tax competition.

Regarding harmful tax practices, the draft Code of Conduct defines them as:

Tax measures by tax havens and/or preferential tax regimes that affect the location of financial and other services activities, erode the tax base of other countries, distort trade and investment patterns and undermine the fairness, neutrality and the broad social acceptance of systems. ${ }^{49}$

Even though not much poor like the definition of harmful tax competition, the definition of harmful tax practices focuses on the consequences without detailing the characteristics of that phenomenon. Rather, it would have included the key characteristics of harmful tax practices such as offering a lower level of taxation than the tax that generally apply, ringfencing, lack of economic substance, lack of transparency, and non-adherence to transfer pricing principles.

The Code's definition of harmful tax effect is also anomalous. According to the draft Code, the harmful tax effect refers to "negative spill over to other countries that arise from the harmful preferential tax regimes. ${ }^{50}$ From this definition, it is as if the spill-over effect can only arise from one component of harmful tax competition, i.e. the harmful preferential tax regimes. Rather, the spill-over effect may arise from the tax havens, and these can even produce the worst harmful effects. In other words, if that definition is taken like that, it would mean that it is confusing the harmful preferential tax regimes with harmful tax practices.

More than that, from the draft Code, it becomes obvious that the way the draft is considering harmful tax competition and harmful tax practices differs totally from the international standards in the matter. Furthermore, the draft Code of Conduct defines harmful tax competition and harmful tax practices as two separate and distinct phenomena. Rather, the two are internationally considered to be the same. Here the reference is the OECD 1998 Report that used the phrase harmful tax competition while the phrase harmful tax practices came in use with the OECD 2001 Progress Report. Thereafter, the two phrases continued to be used interchangeably.

Another serious puzzlement of the draft Code of Conduct is in its article 13. This article mentions a long list of actions that EAC should undertake to eliminate harmful tax prac-

$49 I d$., art. 1(f).

$50 I d$., art. 1(e). 
tices. Such are clustered into three, namely in respect of VAT, in respect of income tax, and in respect of excise taxes. Regarding the VAT, the proposed actions are the:

Development of a common EAC VAT Model; harmonization of zero-rated regimes; harmonization and reduction of exempt transactions; maintaining the border controls; harmonization of tax bases; equalizing the administration and tax procedures.

Regarding income tax, the draft Code of Conduct proposes the:

Review and harmonization of all tax incentives especially those related to the export processing zones and special economic zones; harmonization of initial capital allowances of more than $50 \%$; treat capital gains from capital sales as normal profit; harmonization of losses (carry forward); harmonization of the withholding taxes of dividends, interests payments, royalties and service fees.

Regarding excise taxes, the draft Code proposes the:

Development of a harmonized legal basis for excise taxation by defining the exclusive categories of taxable goods; defining the particular taxable items in a uniform way; replacing the ad valorem rates by specific rates; defining lower and upper ceilings for the national tax rates; determining the specific tax rates in the national excise tax laws; abolishing discriminatory rates for imported goods; harmonizing tax bases for levying excise taxes; and harmonizing excise tax rates.

Most of, if not all, the mentioned actions have nothing to do with harmful tax practices, which further confirms the puzzle over harmful tax competition understanding.

In terms of acceptability, tax competition is generally accepted, while harmful tax competition is generally not accepted. Consequently, the EU and OECD standards aim at fighting against harmful tax competition while preserving good tax competition. This approach is totally different from the EAC, which seems to stand against any tax competition. This can be seen in several reports produced on tax competition in the EAC that simply calculate the revenues foregone due to tax incentives, to conclude the harmfulness of preferential tax rates, along with recommending the elimination of tax incentives. ${ }^{51}$

If the EAC keeps that trend, that I consider unjustifiable, consequences of fighting against tax competition shall stand against the EAC partner states as the losers. This is especially true because the states, while fighting against harmful tax competition, they must still preserve their international competitiveness. This is only possible if the state eliminates

51 IMF, 'Kenya, Uganda and United Republic of Tanzania: Selected Issues' (2008) IMF Country Report No. 08/353, p. 6 and $8<$ www.imf.org/external/pubs/ft/scr/2008/cr08353.pdf > accessed 14/05/2019; TJN \& ActionAid, Tax Justice Network \& ActionAid, 'Tax Competition in East Africa: A Race to the Bottom?' (2012) Nairobi, p. 1; P Abbott et al., 'East African Taxation Project: Rwanda Country Case Study' (2011) IPAR, p. 12. 
bad tax competition, i.e. which is harmful, at the same time preserving good tax competition which is desirable and beneficial to the country and the taxpayers.

Another element in the draft Code of Conduct which is problematic is the Code's scope ratione materiae. In terms of article 2, the Code of Conduct applies to 'each tax of every description'. This scope is too broad and unnecessarily encompasses some irrelevant types of taxes. For instance, considering the nature and the practices of tax competition, tax on land, tax on immovable properties, consumption tax, tax on labor, and the like, are not concerned with harmful tax competition. Some other taxes also have de minimis impact and are meaningless to lower the burden of tax and cannot, therefore, influence the business location. This is an instance of trading license tax in Rwanda, which is between 4,000 Frw (approximately 5 USD) and 250,000 Frw (approximately 275 USD) per annum. ${ }^{52}$

It is worth to mention that the above-mentioned puzzles are indicative and not exhaustive. Besides, there is also an issue of the paucity of legal studies over harmful tax competition in the EAC. This is the subject of the next sub-section.

\section{Paucity of legal studies on (harmful) tax competition}

From a legal perspective, very few studies have been done on tax competition in the EAC. While I acknowledge the researchers' contributions to that matter, very few legal studies are available. Consequently, the study of harmful tax competition in the EAC is dominated by economic studies. Rather, economic considerations of harmful tax competition differ from the legal considerations.

In brief, economists' major concern when studying tax competition is about the use of tax rates and tax bases to attract productive investment which ends up with a risk to eventually fall to zero tax rates ${ }^{53}$ as a result of the race to the bottom. This is when the lawyers' major concern is centered on the states' freedom to choose their own tax system at the same time fairly sharing the taxing rights. The fair sharing of taxing rights has been qualified as an issue of having an income reported in a particular country. ${ }^{54}$ Thus, it becomes problematic when the taxing right is mismatching the production movement. In other words, the problem arises out when an income is reported in a country but without an associated movement of production. ${ }^{55}$ In other words, lawyers, when studying tax competition, are interested in determining whether or not the taxing rights are fairly shared, to decide whether a given practice is within the parameters of permitted tax competition practices.

52 Law No. 75/2018 of 07/09/2018 determining the sources of revenue and property of decentralized entities, O.G. No. 44 of 29/10/2018, Annex.

53 I Calich, The Impact of Globalization on the Position of Developing Countries in the International Tax System (Ph.D Thesis, The London School of Economics and Political Science 2011), p. 60.

54 R Griffith and A Klemm, 'What Has Been the Tax Competition Experience of the Last 20 Years' (2004) The Institute for Fiscal Studies WP04/05, p. 4.

55 Ibid. 
Therefore, what may be true for economists may not necessarily be the same for lawyers. This is why, contrary to a general myth that the EAC is seriously engaged in harmful tax competition, a legal analysis reveals the opposite. This is especially true if one considers the absence of enforceable legal rules or standards that can be based on to determine the extent of engagement in harmful tax competition by the EAC partner states.

\section{F. What are the ways forward?}

First, it is worth to mention that EAC is well positioned to effectively regulate harmful tax competition. This affirmation is based on the EU success in such endeavors as a regional integration organization. The EAC is also well positioned compared to individual partner states initiatives. This is based on the international nature of (harmful) tax competition. Thus, international responses are likely to be more effective than national responses. This has been affirmed by the OECD, which found unilateral responses to be limited to deal with a problem which is global. ${ }^{56}$ The ineffectiveness of unilateral measures is also evidenced by the fact that if one country unilaterally eliminates preferential treatments, the activities may move to other countries that continue to offer preferential treatments. Hence, the OECD advises for international cooperation to avoid the risk that may thereto be associated. ${ }^{57}$

Given these points, several specific actions need to be undertaken at the EAC level. Without pretending to provide an exhaustive list, one proposal is to speed up the adoption of the EAC Draft Code of Conduct against harmful tax competition in the Community. Considering the political nature of the Code of Conduct, the EAC Council acting within its mandate as the EAC's policy organ, ${ }^{58}$ is well positioned to adopt the Code of Conduct. In consideration of harmful tax competition seriousness, it is recommended to the Council to adopt the Code of Conduct as a directive. In this form, the Council shall set the goal to be reached by the EAC partner states but each state shall remain free to choose the form and the method of transposing the principles therein contained. Adopting the draft Code of Conduct as a directive will also mean that it is legally binding. In consequence, failure to respect it shall result in sanctions, including judicial sanctions, which may positively contribute to its respect. Unilaterally transposing the Code into the national legal system will also comfort the partner states, as they shall feel their sovereignty less infringed.

However, before the adoption, there is a need to make some corrections that may hamper the Code's effectiveness if left unchecked. One of these needful corrections is article 1(d) and (f) on the definitions of harmful tax competition and harmful tax practices. First of all, these should not be separated. They should rather be considered as synonymous with interchangeable use. The definition should also be clear that tax competition itself is not

56 OECD 1998 (n 4) p. 37.

57 Id., p. 38; B Dickinson and N Nersesyan, OECD Tax and Development: Principles to Enhance the Transparency and Governance of Tax Incentives for Investment in Developing Countries, p. 4 $<$ www.oecd.org/ctp/tax-global/transparency-and-governance-principles.pdf $>$ accessed 23/04/2020.

58 EAC Treaty (n 12) art. 14(1). 
problematic, that what is problematic is when the tax competition escalates into harmful tax competition. Article 3 on the standstill and rollback clauses should be rectified to provide a definite timeframe for the partner states to roll back the legal provisions and practices that relate to harmful tax practices.

Article 7 of the draft Code of Conduct also needs to be rephrased before adoption. This article reads that partner states with negotiable tax rates and bases are advised to review them. Legally speaking, it would not be useful to simply advise a partner state with a regime of negotiable tax rates or bases because advising implies accepting or rejecting advice. Here, the Code should use a term that expressly conveys an obligation of eliminating or discontinuing negotiable tax rates or bases. In the same vein, article 12(4)(a) of the draft Code of Conduct should be revised. In its current status, if a partner state provides state aid or subsidy that constitutes harmful tax competition, other states are allowed to do the same. In fact, this would be an unreasonable solution of legalizing malfeasance. This provision would rather be eliminated as the rest of the provisions are enough to provide solutions to the cases of harmful tax competition. This is especially true for article 12(4)(b) which requires the partner states to review and abolish or amend policies that amount to harmful tax competition.

Another provision that needs to be corrected is article 17(3). This article considers as exceptional cases tax measures that are granted for the economic development of particularly disadvantaged regions, even if such tax measures would normally be qualified as harmful. On this provision, it should be added that the same applies to similar measures that are granted to support the economic development of particularly disadvantaged sectors. With reference to the EU practices, ${ }^{59}$ it should also be made clear that the support should be proportional to the level of disadvantage.

Furthermore, the scope ratione materiae of the Code of Conduct as set out in article 2(1) of the draft needs to be revised because it is too vague. This article mentions that the Code applies to each tax of every description. This scope is too problematic because, as mentioned in the second sub-section of the fifth section, several taxes have nothing to do with harmful tax competition. For the sake of clarity, this article should set limitations and specify that the concern is about business taxation.

Besides the corrections, the Code of Conduct should clearly specify its enforcement mechanisms. These are very important as they broadly contribute to the Code's success or failure. Thus, it is important to highlight elements such as the enforcing organs and enforcement procedures. In this respect, the proposal is to have the Code of Conduct enforced by a Committee of Experts as proposed in the draft Code. The Committee should be empowered enough and its decisions should be considered binding. However, any party to the Commit-

59 Council of the European Union, Report on Code of Conduct Group assessment of Vietnam's Disadvantaged areas regime (VN005), 14114/19 ADD 10 FISC 444 ECOFIN 1005, Brussels, 25/11/2019, p. 3; K Dirix, 'Harmful Tax Competition: Six Belgian Tax Incentives under the Microscope’ (2013) EC Tax Review 5, p. 236. 
tee proceedings that disagrees with the Committee's outcome should be given the right to take the matter to the EACJ for a final decision.

Last but not least, there is a need of demystifying the myth of tax competition in the EAC. In fact, besides the puzzles mentioned in the second sub-section of the fifth section, there is a general trend in the EAC of considering tax competition and preferential tax regimes as bad things. That is mainly because of the confusion between tax competition per se and harmful tax competition. Thus, there is a need to push further the understanding that all tax competitions are not harmful.

\section{G. Conclusion}

This paper aimed at presenting the precarious state of regulating harmful tax competition in the EAC. To this end, it first introduced the EAC and its legal order, to which followed a summarized understanding of harmful tax competition. That set the ground to enter the core subject of this paper in three stances: the current regulatory framework, the challenges thereto related, and the formulation of the proposals to overcome that situation.

Regarding the current status, this paper showed how the current regulation is poor and weak to counteract harmful tax competition. This is due to the fact that, apart from the disparate provisions in the Treaty that broadly relate to tax competition, the Code of Conduct that was specifically drafted to tackle harmful tax competition in the Community has not been adopted and is not yet into force. Besides, the weak regulation is fueled by several challenges such as a low political will, intra-community misunderstanding, paradoxical understanding of harmful tax competition, and an unjustified low interest of lawyers to study harmful tax competition. To revamp the current situation, part of the recommendations is to polish the draft Code of Conduct followed by a quick adoption by the EAC Council in a form of a directive. There is also a need of demystifying the myth of harmful tax competition in the EAC by unfolding the factors of harmful tax competition instead of limiting only to preferential tax rates.

In consideration of all previously said, it is apparent that the area of tax competition is not a priority in the EAC legal order. Even though, the negative consequences of harmful tax competition are obvious and the EAC partner states are in no way saved from suffering them. Thus, in conclusion, the questions remain: for how long shall the draft Code of Conduct against harmful tax competition in the EAC remain a draft? And for how long shall the EAC continue to disregard the problems of harmful tax competition? 